\title{
Evaluation of Classroom Furniture Design for Ecuadorian University Students: An Anthropometry-Based Approach
}

Pablo Pérez-Gosende ${ }^{1,2, *}$

${ }^{1}$ Grupo de Investigación Interdisciplinar en Matemática Aplicada (GIIMA), Universidad Politécnica Salesiana, 090109, Ecuador

${ }^{2}$ Centro de Investigación en Gestión e Ingeniería de Producción (CIGIP), Universitat Politècnica de València, Alcoy, 03801, Spain

\section{A R T I C L E IN F O}

Article history:

Received: 07 August, 2019

Accepted: 22 October, 2019

Online: 25 November, 2019

Keywords:

Anthropometry

Ergonomic design

Design evaluation

Musculoskeletal disorders

Classroom furniture

\begin{abstract}
A B S T R A C T
It is widely known that students' exposure to poor postures due to inappropriate classroom furniture design may contribute to the increase of the prevalence of musculoskeletal disorders symptoms that if not identified on time could lead to severe health issues. In this context, due to the unavailability of scientific studies related to this topic in Ecuador, the aim of this research is twofold. The first aim was to define the classroom furniture design parameters' dimensions for university students according to relevant anthropometric information. The second aim is to conduct a preliminary diagnostic of the appropriateness of classroom furniture currently used in Ecuadorian universities to students' anthropometric characteristics. The obtained results are particularly relevant as the ten design parameters here proposed could be the starting point to the creation of a specific Ecuadorian standard to regulate classroom furniture design for university students. That would ensure domestic and foreign manufacturers could offer furniture more secure and adequate to the anthropometric characteristics of the university population of Ecuador. On the other hand, the preliminary study found evidence that all the examined classroom furniture presented mismatches in at least five design parameters, and students exposed to them over the past twelve months had a high prevalence of symptoms of musculoskeletal disorders in the hips, back, thighs, and neck.
\end{abstract}

\section{Introduction}

Anthropometry is the sub-branch of physical anthropology that studies the measurements of the human body in terms of the dimensions of bone, muscle and adipose tissue [1]. These measurements are vital for proper workstations design to prevent musculoskeletal disorders in the workforce [2,3] and at the same time, to facilitate the performance of labor activities with higher productivity $[4,5]$.

Consideration of anthropometric information in classroom furniture design allows students to acquire higher levels of comfort [6], to reduce the presence of musculoskeletal disorders [7-11] and to facilitate the understanding of the knowledge imparted [12,14].

From the ergonomic point of view, three principles of design are known for the application of anthropometric information: the design for the average individual, for extreme individuals, and for an adjustable interval [15]. The latter has been the most suggested

\footnotetext{
${ }^{*}$ Corresponding Author: Pablo Pérez-Gosende, pperezg@ups.edu.ec
}

by researchers in the design of school furniture [16-18], however, it is the least feasible from an economic point of view. From a technical perspective, the first one mentioned is the least recommended design principle as it guarantees comfort only for $50 \%$ of the population.

In general, the design principle for extreme individuals has been the most used in classroom furniture design [17]. It is based mainly on the idea that if the most relevant dimension of the design is suitable for extreme cases (5th or 95th percentile of the corresponding anthropometric measure), then it will guarantee comfort to the majority of the population.

Under this last principle of design, numerous international studies have identified discrepancies between the dimensions of classroom furniture and the anthropometric measures of its target audience: students of basic education [17,19-21], upper secondary education (between 15 and 18 years) [22, 23]; and university students (between 18 and 30 years) [24].

The few Ecuadorian studies that analyze ergonomic or anthropometric principles for school furniture design, do so for 


\section{P. Pérez-Gosende. / Advances in Science, Technology and Engineering Systems Journal Vol. 4, No. 6, 163-172 (2019)}

boys and girls in preschool education [25] or students at the levels of Basic Education [26]. In the latter case, work for children with motor impairment $[27,28]$ stands out. In national scientific literature, studies that address this subject for university students are even scarcer.

The use of inappropriate classroom furniture is one of the causes that favor students in adopting poor postures while performing intraclass academic activities [14-16]. Some studies have concluded that when these postures are sustained over a long period of time, it is considered a risk factor in the development of musculoskeletal disorders [7,22,23].

Musculoskeletal disorders comprise a wide variety of degenerative and inflammatory diseases in the locomotor apparatus [29]. They are characterized by concomitant and nonconcomitant symptoms that comprise pain caused by inflammation, paresthesia, strength loss, fatigue, and difficulty or incapacity to perform certain movements [30,31]. This group of injuries occurs more frequently in works that require important physical activity, weight carrying, repetitive movements, application of forces and as a consequence of bad postures sustained over long periods of time [32].

In order to detect the prevalence of musculoskeletal disorders symptoms (MDS), the Nordic Musculoskeletal Questionnaire (NMQ) designed and validated by Kuorinka [33], has been an instrument of extended use in the context of ergonomic or occupational health studies [29,30,32,34-36]. It allows the identification of initial symptoms, which have not yet triggered diseases or have not yet led the affected patients to consult the doctor. Consequently, its value lies in providing information that makes it possible to proactively estimate the level of risks and avoid exposure to them through corrective measures.

The unavailability of anthropometric databases in Ecuador for adults could imply that the classroom furniture currently in use by students in universities may not be in accordance with their anthropometric characteristics. According to this, their exposure to classroom furnishings for a long period of time could increase the prevalence of MDS, which could lead to serious musculoskeletal disorders and its irreversible consequences if not detected on time.

In this context, this paper aims to define standards for the design parameters of classroom furniture for university students in Ecuador, in accordance with relevant anthropometric information. Based on these standards, classroom furniture used in a sample of universities in Guayaquil is evaluated. In addition, MDS prevalence is measured in students who use such furniture in their daily academic activities and also possible risk factors are inquired.

\section{Methods}

For school furniture design, the anthropometric measurements considered relevant in this study are presented in Figure 1.

\subsection{Anthropometric information}

There are no official anthropometric databases in Ecuador. However, Lema-Barrera [37] made precise estimates of anthropometric measures selected for the 5,50 and 95 percentiles of the adult Ecuadorian population of both sexes and self- identified according to three ethnic origins: afro-Ecuadorians, indigenous and mestizos. This secondary information was used as the basis of calculation in this research. The mean and standard deviation values of these measures are presented in Table 1.
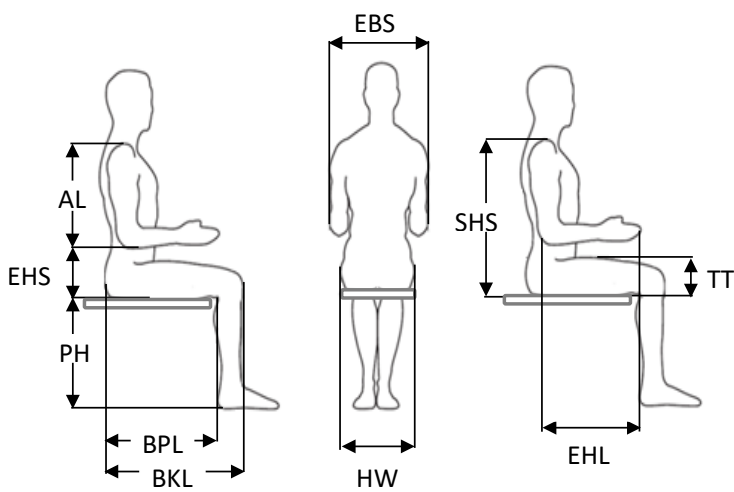

Figure 1: Relevant anthropometric dimensions for school furniture design: Arm length (AL); Elbow height sitting (EHS); Popliteal height (PH); Butock-knee length (BKL); Buttock popliteal length (BPL); Elbow breadth sitting (EBS); Hip width (HW); Shoulder height sitting (SHS); Elbow-hand length (EHL); Thigh thickness (TT).

Table 1: Population mean and standard deviation $(\mathrm{mm})$ of selected anthropometric measures for Ecuadorian men and women per ethnic group

\begin{tabular}{|c|c|c|c|c|c|c|}
\hline \multirow{2}{*}{ Parameters } & \multicolumn{2}{|c|}{ Mestizos } & \multicolumn{2}{c|}{ Indigenous } & \multicolumn{2}{c|}{$\begin{array}{c}\text { Afro- } \\
\text { Ecuadorians }\end{array}$} \\
\cline { 2 - 7 } & $\mathrm{M}$ & $\mathrm{F}$ & $\mathrm{M}$ & $\mathrm{F}$ & $\mathrm{M}$ & $\mathrm{F}$ \\
\hline \multirow{2}{*}{ AL } & 363 & 347 & 371 & 330 & 390 & 341 \\
& $(17.0)$ & $(27.5)$ & $(34.6)$ & $(23.4)$ & $(25.9)$ & $(26.5)$ \\
\hline \multirow{2}{*}{ EHS } & 232 & 235 & 220 & 231 & 209 & 225 \\
& $(29.6)$ & $(27.9)$ & $(66.2)$ & $(25.6)$ & $(19.7)$ & $(20.7)$ \\
\hline \multirow{2}{*}{ PH } & 415 & 386 & 415 & 396 & 486 & 404 \\
& $(30.4)$ & $(30.2)$ & $(34.5)$ & $(41.6)$ & $(27.9)$ & $(28.5)$ \\
\hline \multirow{2}{*}{ BKL } & 571 & 541 & 552 & 527 & 584 & 531 \\
& $(36.0)$ & $(31.6)$ & $(31.7)$ & $(34.2)$ & $(26.8)$ & $(27.3)$ \\
\hline \multirow{2}{*}{ BPL } & 464 & 437 & 461 & 433 & 493 & 429 \\
& $(38.6)$ & $(27.4)$ & $(15.6)$ & $(33.7)$ & $(24.8)$ & $(29.5)$ \\
\hline \multirow{2}{*}{ EBS } & 447 & 400 & 448 & 456 & 499 & 388 \\
& $(40.6)$ & $(40.3)$ & $(62.8)$ & $(30.7)$ & $(21.4)$ & $(34.6)$ \\
\hline \multirow{2}{*}{ HW } & 356 & 356 & 379 & 391 & 406 & 361 \\
& $(25.1)$ & $(26.3)$ & $(30.2)$ & $(32.0)$ & $(18.9)$ & $(25.7)$ \\
\hline \multirow{2}{*}{ EHL } & 503 & 466 & 503 & 448 & 524 & 476 \\
& $(23.9)$ & $(30.6)$ & $(32.3)$ & $(30.4)$ & $(28.0)$ & $(23.2)$ \\
\hline \multirow{2}{*}{ TT } & 132 & 124 & 131 & 123 & 153 & 122 \\
& $(19.7)$ & $(17.4)$ & $(20.5)$ & $(19.6)$ & $(12.8)$ & $(09.7)$ \\
\hline
\end{tabular}

Note: Mean (standard deviation). Source: Adapted from [38].

Anthropometric measurement values of the Ecuadorian population are very heterogeneous [37]. According to this, it is important to define an approach strategy to guarantee comfort to $95 \%$ of people who could use school furniture. For this reason, this study will consider the measures of the biggest ethnic group in Ecuador. In this respect, according to the results of the 2001 and 2010 national censuses [38,39], mestizos represent the largest percentage of the population in Ecuador as shown in Figure 2.

To estimate extreme values for each relevant anthropometric measurement, the 5th percentile of the sex with the lowest 


\section{P. Pérez-Gosende. / Advances in Science, Technology and Engineering Systems Journal Vol. 4, No. 6, 163-172 (2019)}

dimension and the 95th percentile of sex with the highest were taken among the mestizo population.

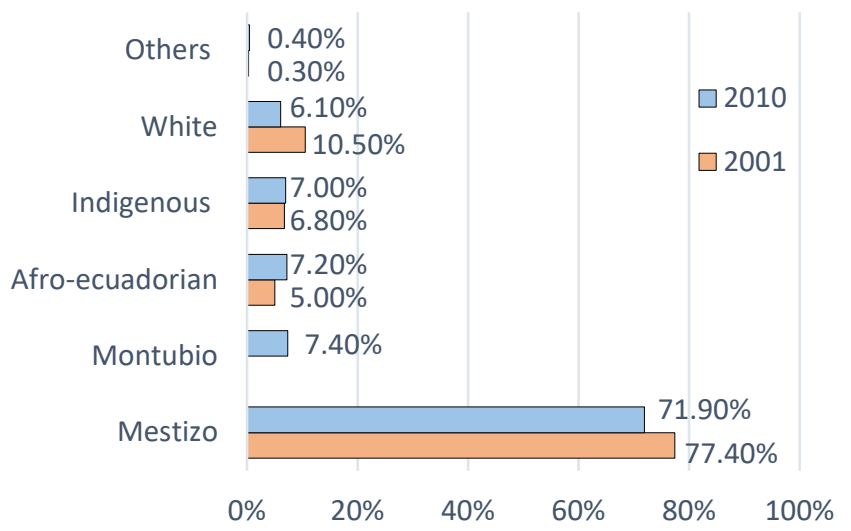

Figure 2: Ethnic self-identification in Ecuador according to 2001 and 2010 national censuses

\subsection{School furniture design parameters}

This section presents the mathematical formulae to estimate the design parameters of classroom furniture considering the casuistically relevant anthropometric measures and the biomechanics of the individual in a sitting position.

As an example, Figure 3 shows the design parameters of school furniture composed of a table and a chair. However, in Ecuadorian universities, it is also common to find chairs with mounted desktop.

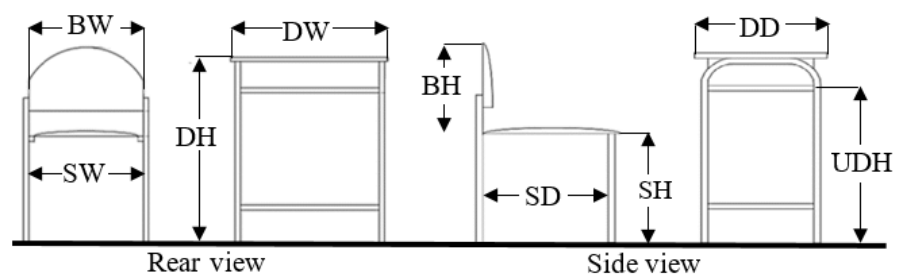

Figure 3: Representation of classroom furniture design parameters: Backrest width (BW), Seat width (SW), Seat height (SH), Backrest height (BH), Seat depth (SD), Desk height (DH), Desk width (DW), Desk depth (DD) and Under-desk height (UDH).

Traditionally seat height $(\mathrm{SH})$ has been related to popliteal height $(\mathrm{PH})$, which is measured from the ground to the popliteal fossa of the person sited with erected trunk [40]. The human being, when sitting, does it on the ischial tuberosities, which are bony structures that morphologically do not allow to maintain the balance of the body in this position [41]. To achieve such a balance, support is required in the back and feet. The seat height, on the other hand, must be shorter than popliteal height so that legs can lean forward between $5^{\circ}$ and $30^{\circ}$ regarding the vertical axis of the body [22]. These biomechanical considerations are considered in (1), where CC is a footwear correction.

$$
(P H+C C) \cos 30^{\circ} \leq S H \leq(P H+C C) \cos 5^{\circ}
$$

This equation has been widely used in research aiming to find an eventual mismatch between classroom furniture and the anthropometric characteristics of students who regularly use them
$[4,11,17,19,21,22]$. In this study the 5 th $\mathrm{PH}$ percentile for mestizo women was used and a CC value equivalent to $20 \mathrm{~mm}$.

According to ISO 9241-5: 1998, the seat width (SW) should be longer than the hips width (HW) of the person while seated to facilitate the adaptation of the chair to the changing needs of the individual [42]. In this regard, (2) has been regularly used in analogous researches [4,22] and implies that the appropriate seat width should vary between $10 \%$ and $30 \%$ of HW. Specifically, in this study, the 95th percentile of the hip width of mestizo women was used.

$$
1,1 H W \leq S W \leq 1,3 H W
$$

ISO 9241-5: 1998 establishes that the adequacy of seat depth (SD) is achieved when it is shorter than the user's poplitealbuttocks length (BPL) [42]. This relays on the idea that the popliteal fossa should be free to ease blood supply to the legs. Consequently, some researchers have agreed that the appropriate dimension for SD should lie within the interval of $80 \%$ to $95 \%$ of BPL [5,11,20-22] as shown in (3). In this study, the 5th percentile of mestizo women's BPL was employed.

$$
0,80 B P L \leq S D \leq 0,95 B P L
$$

Some authors suggest that upper backrest height $(\mathrm{BH})$ should measure between $60 \%$ to $80 \%$ shoulder height (SHS) to ease mobility in the upper trunk $[11,17,21,22]$. The secondary anthropometric information available does not include data from this measure. However, since the SHS matches the sum of the arm length (AL) and the elbow height of the person in a seated position (EHS) according to [41], an equivalent form of calculation is presented in (4). There, EHS represents the 5th percentile of men and $\mathrm{AL}$ the 5 th percentile of women.

$$
0,6(E H S+\mathrm{AL}) \leq B H \leq 0,8(E H S+\mathrm{AL})
$$

The seatback width (BW) has not been widely discussed in the literature as noted in [17]. However, some authors have come to the agreement that for BW the width of the hips (HW) can be considered the relevant anthropometric measure $[16,18]$. In this regard, we decided BW be longer than the 95 th percentile of $\mathrm{HW}$ for mestizo women, as shown in (5).

$$
B W \geq \mathrm{HW}
$$

The under-desk height (UDH) must allow the sliding of the user seated towards the interior of the table. Thus, the ideal measurement should include seat height, seated thigh thickness (TT) and clearance $(20 \mathrm{~mm})$ to facilitate the change of posture of the legs in this position. These considerations are included in (6). Here, TT corresponds to the 95th percentile for men and $\mathrm{PH}$ to the 5 th percentile for women.

$(P H+C C) \cos 30^{\circ}+T T+20 \leq U D H \leq(P H+C C) \cos 5^{\circ}+$ $T T+20$

For desk height (DH) estimation, previous research has taken into account the biomechanics of the shoulder and have 


\section{P. Pérez-Gosende. / Advances in Science, Technology and Engineering Systems Journal Vol. 4, No. 6, 163-172 (2019)}

considered acceptable flexion angles from $0^{\circ}$ to $25^{\circ}$ and abduction angles between $0^{\circ}$ and $20^{\circ}$ for this joint $[4,5,11,21]$. Such authors have used (7). However, in the absence of SHS measurements and considering it equivalent to the sum of EHS and AL, the above expression can conveniently be converted to (8), which was used in this research to determine the match standard for DH. In this case, $\mathrm{PH}$ and $\mathrm{AL}$ correspond to the 5th percentile for women, while EHS corresponds to the 5 th percentile for men.

$$
\begin{aligned}
& E H S+\left[(P H+C C) \cos 30^{\circ}\right] \leq D H \leq\left[(P H+C C) \cos 5^{\circ}\right]+ \\
& 0,8517 E H S+0,1483 S H S \\
& E H S+\left[(P H+C C) \cos 30^{\circ}\right] \leq D H \leq\left[(P H+C C) \cos 5^{\circ}\right]+ \\
& E H S+0,1483 A L
\end{aligned}
$$

According to [19], the design of the table depth (DD) and the table width (DW) have been sparsely discussed in the literature. Table depth is important to provide enough space for the user to change the posture of the lower part of the body. Thus, we consider that this dimension should exceed the 95th percentile of men knee-toback length (BKL). This assumption is also true for the tablet length (TL) in chairs with mounted desktops. Consequently, the lower limit of these two design parameters will be estimated through (9).

$$
D D \geq B K L
$$

The width of the table (DW), on the other hand, should allow the users to rest their two forearms on the surface at the same time, whether they are upright or abducted in a relaxed posture. In this case, some authors have considered theoretical reference positions with a shoulder abduction angle between $0^{\circ}$ and $20^{\circ}$ $[5,20,21]$. Thus, in this study it was considered that the minimum acceptable table width should include: the length from elbow to elbow of the person while seated (EBS) corresponding to the 95th percentile of men, the distance that produces the abduction of the shoulders on the plane (equivalent to $2 \mathrm{ALsen} 20^{\circ}$ ) considering the 95th percentile of AL for women and a $20 \mathrm{~mm}$ slack on each side as in (10).

$$
D W \geq E B S+(0,684 A L)+40
$$

In addition to individual tables and chairs, Ecuadorian higher education institutions usually tend to purchase chairs with sidemounted desktop as classroom furniture. However, despite being so common, scarce attention has been given in the scientific literature to the ergonomics of its design [16]. All chair design parameters mentioned in this section are equivalent to those used in side-mounted desktop chairs ( $\mathrm{SH}, \mathrm{SW}, \mathrm{SD}, \mathrm{BW}$, and $\mathrm{BH}$ ). Similarly, the anthropometric criteria considered above for the design of the desk height (DH) and its depth (DD) correspond to those required for the design of tablet height for side-mounted desktop chairs (TH) and its length (TL), respectively. It is only necessary to specify a design criterion for tablet width (TW).

In this study, the minimum width of the tablet in chairs with side-mounted desktop should include half of EBS, plus the distance that implies the maximum acceptable abduction of the elbow at $20^{\circ}$ as suggested in $[4,5,11,21]$ and $20 \mathrm{~mm}$ of slack. However, TW should not exceed the 95th percentile of elbowhand length (EHL, which is measured from the elbow to the tip of the middle finger in a seated position), since it would make it difficult for the student to access and leave the seat. All these considerations are presented in (11).

$$
0,5 E B S+(0,342 A L)+20 \leq T W \leq E H L
$$

\subsection{Data collection}

Having secondary dataset on relevant anthropometric measurements of the adult population in Ecuador at hand, the sampling strategy focused on measuring, on the one hand, the main parameters of school furniture design in Guayaquil universities, and on the other hand, the prevalence of possible musculoskeletal disorders symptoms (MDS) in students who use such furniture on a daily basis.

The sample size was calculated considering an infinite population with a confidence level of $95 \%$ and a margin of error of $4 \%$. The resulting value was 601 individuals taking into account a proportion of successes and failures of $50 \%$. Among the 13 functional universities in Guayaquil, 5 were randomly selected. Then, in each institution, five classrooms were selected through a simple random sampling. For each identified furniture model, ten measurements were made of each of the ten design parameters considered relevant by the study authors (as shown in Figure 3). Such measurements were made with the use of a flexometer tape. The arithmetic mean was the measure of central tendency used to characterize every furniture design parameter dimension.

Next, the NMQ was used to identify MDS prevalence in students as a consequence of an eventual mismatch between the school furniture and their anthropometric characteristics. Its application was made in a self-administered way to those students who were willing to collaborate anonymously and who were not involved in work relations to any company in the last twelve months.

The questionnaire consisted of two general questions. The first one evaluated the presence of any MDS (pain, discomfort or numbness) over the last year in nine body parts (neck, shoulders, elbows, hands/wrists, upper back, lower back, hips/thighs/buttocks, knees, ankles/feet). The second question identified whether the presence of MDS within the last year would have prevented the user from doing any of their everyday domestic or entertainment activities. The questionnaire also recorded the age, height, weight, sex, ethnic self-identification, laterality, study time in Higher Education and the average number of hours per week that students spent seated.

The weight and height of the students were also measured using a Tanita UM-076 scale and a SECA 217 stadiometer, respectively. This information was used to determine the body mass index (BMI) of every polled individual. The data collection was carried out between October 2018 and April 2019.

\subsection{Statistical analysis}

The information collected was processed using the statistical 


\section{P. Pérez-Gosende. / Advances in Science, Technology and Engineering Systems Journal Vol. 4, No. 6, 163-172 (2019)}

package IBM SPSS Statistics 22.0. The normal distribution of data for age, height, weight, study time, sitting hours per week, and students' body mass index was measured using the Kolmogorov-Smirnov test with correction of significance of Lilliefors to a significance level of $p<0.05$. The characteristics of participants were presented as proportions or percentages in the case of categorical variables and the mean and standard deviation for normal continuous variables. MDS prevalence differences for the $\mathrm{k}$ identified furniture models were assessed using the chisquare test at a significance level of $\mathrm{p}<0.05$.

Associations between MDS prevalence and some variables suspected of being risk factors (gender, laterality, age, BMI, number of hours per week seated, years of higher education and type of furniture) were measured using the Odds Ratio (OR) with a confidence level of $95 \%$.

\section{Results}

Using the formulae presented in the previous section, the compatibility ranges for the ten design parameters for university school furniture were calculated and are provided in Table 2. These ranges, theoretically assure the proper comfort to $95 \%$ of the university student population self-identified as mestizo.

Table 2: Match intervals of school furniture design parameters for university students in Ecuador

\begin{tabular}{|l|c|c|}
\hline Parameter & $\begin{array}{c}\text { Lower bound } \\
(\mathrm{mm})\end{array}$ & $\begin{array}{c}\text { Upper bound } \\
(\mathrm{mm})\end{array}$ \\
\hline Desk height (DH) & 509 & 603 \\
\hline $\begin{array}{l}\text { Under-desk height } \\
\text { (UDH) }\end{array}$ & 510 & 560 \\
\hline Desk width (DW) & 822 & - \\
\hline $\begin{array}{l}\text { Desk depth / Tablet } \\
\text { length (DD/TL) }\end{array}$ & 630 & - \\
\hline Seat height (SH) & 326 & 375 \\
\hline Backrest height (BH) & 291 & 388 \\
\hline Seat depth (SD) & 313 & 372 \\
\hline Seat width (SW) & 440 & 519 \\
\hline Backrest width (BW) & 400 & - \\
\hline Tablet width (TW) & 411 & 500 \\
\hline
\end{tabular}

From the above, it is clear that the ideal area for the seat should be between $0.138 \mathrm{~m}^{2}$ and $0.192 \mathrm{~m}^{2}$, the minimum surface area of the table should measure $0.518 \mathrm{~m}^{2}$ and in the case of side-mounted desktop chairs, the minimum area recommended for the tablet is $0.259 \mathrm{~m}^{2}$.

The ten design parameters were measured in nine models of furniture that are used in five universities in the city of Guayaquil. Among these, two universities are public (identified as B and D), and the three remaining are co-financed by the Ecuadorian government (A, C and E). University A and D employ a single type of furniture composed of individual tables and chairs. These have been identified as M1 and M6 respectively. University B uses two models, a side-mounted desktop chair (M2) and an individual table and chair station (M3). University $\mathrm{C}$ uses two different models of side-mounted desktop chairs (M4 and M5) and University E uses three of the same (M6, M7, and M8).

Table 3 shows the evaluation results of the nine types of furniture analyzed with respect to the computed compatibility ranges.

A second part of the study consisted of analyzing the prevalence of MDS in the student population that uses this furniture on a daily basis. For this, the NMQ was applied to a total sample of 672 students, however, only 628 questionnaires were valid, guaranteeing a real margin of error of $3.9 \%$. The sample sizes according to the universities studied and the furniture models identified are presented in Table 4.

The majority of respondents identified themselves as mestizos (88.28\%). $45.75 \%$ of the total were female and $54.25 \%$ male. $89.25 \%$ said they were right-handed and $10.75 \%$ were left-handed. The mean age was 21.45 years $(\mathrm{SD}=0.129$ years). The mean height was $165.57 \mathrm{~cm}(\mathrm{SD}=0.455 \mathrm{~cm})$, the mean weight was 66.23 $\mathrm{kg}(\mathrm{SD}=0.497 \mathrm{~kg})$ and the mean $\mathrm{BMI}$ was $24.91 \mathrm{~kg} / \mathrm{cm} 2$ $(\mathrm{SD}=0.535 \mathrm{~kg} / \mathrm{cm} 2)$. On average, these students sat in their school furniture 21.22 hours a week during the last year of school $(\mathrm{SD}=0.448$ hours) and the average length of stay in Higher Education was 33.49 months ( $\mathrm{SD}=0.669$ months).

Table 5 shows MDS prevalence according to its anatomical classification, for the study population. As might be noted, the highest annual MDS prevalence occurred in the neck, along the entire spine (upper and lower back) and in the hips/thighs.

In general terms, between $86.28 \%$ and $91.24 \%$ of university students who used these nine furniture models on a daily basis over the last year, felt musculoskeletal discomfort in at least one place in their body. More specifically, it can be affirmed with $95 \%$ confidence that between $59.78 \%$ and $67.34 \%$ suffered some discomfort in the neck; between $53.41 \%$ and $61.19 \%$ felt such symptoms in the upper back and between $50.66 \%$ and $58.48 \%$ in the lower back. It is important to notice that the lowest MDS prevalence was located in elbows with $21.83 \%$ (95\% CI: 0.186$0.251)$.

Problems along the spine appear to have had a greater impact on the health detriment and well-being of students. The upper back ailments prevented $34.35 \%$ of them (95\% CI: $0.306-0.381$ ) from performing their usual activities in the last year. On the other hand, those discomforts related to lower back made it impossible for $37.56 \%$ of them ( $95 \%$ CI: $0.338-0.414$ ) to perform their daily non-academic activities.

In detail, Table 6 shows the annual MDS prevalence differences for the 9 samples of students according to the model of furniture used in their daily academic activities. As can be appreciated, such differences are significant $(\mathrm{p}<0.05)$. This also shows that there is a relationship of dependence between the type of furniture and the presence of MDS in some parts of the body.

The neck-related annual MDS prevalence had a greater impact on students who used furniture model number eight $(100 \%$ prevalence) and number five (88.24\%), although this sort of prevalence was also relatively high for the remaining furniture models (greater than 50\%) with the exception of the number nine. Particularly, those students who used furniture number five had a greater impact on their health. In fact, $48.53 \%$ of them were 
Table 3: Match between school furniture and the ideal design parameters dimensions

\begin{tabular}{|c|c|c|c|c|c|c|c|c|c|}
\hline \multirow{2}{*}{$\begin{array}{c}\text { Design } \\
\text { parameters }\end{array}$} & \multirow{2}{*}{ A } & \multicolumn{2}{|c|}{ B } & \multicolumn{2}{|c|}{$\mathrm{C}$} & \multirow{2}{*}{$\begin{array}{c}\mathrm{D} \\
\mathrm{M} 6 \\
\end{array}$} & \multicolumn{3}{|c|}{$\mathrm{E}$} \\
\hline & & M2 & M3 & M4 & M5 & & M7 & M8 & M9 \\
\hline $\mathrm{DH}$ & $730^{\mathrm{b}}$ & $660^{\mathrm{b}}$ & $720^{b}$ & $660^{\mathrm{b}}$ & $760^{\mathrm{b}}$ & $721^{b}$ & $671^{\mathrm{b}}$ & $721^{b}$ & $761^{b}$ \\
\hline UDH & $590^{\mathrm{b}}$ & $640^{\mathrm{b}}$ & $670^{\mathrm{b}}$ & $631^{\mathrm{b}}$ & $731^{b}$ & $670^{\mathrm{b}}$ & $650^{\mathrm{b}}$ & $700^{b}$ & $740^{\mathrm{b}}$ \\
\hline DW & $600^{\mathrm{a}}$ & & $681^{\mathrm{a}}$ & & & $510^{\mathrm{a}}$ & & & \\
\hline $\mathrm{DD} / \mathrm{TL}$ & $320^{\mathrm{a}}$ & $450^{\mathrm{a}}$ & $391^{\mathrm{a}}$ & $300^{\mathrm{a}}$ & $300^{\mathrm{a}}$ & $360^{\mathrm{a}}$ & $300^{\mathrm{a}}$ & $350^{\mathrm{a}}$ & $300^{\mathrm{a}}$ \\
\hline SH & $420^{\mathrm{b}}$ & $400^{\mathrm{b}}$ & $430^{\mathrm{b}}$ & $431^{\mathrm{b}}$ & b 450 & $430^{\mathrm{b}}$ & $430^{\mathrm{b}}$ & $430^{\mathrm{b}}$ & $500^{\mathrm{b}}$ \\
\hline $\mathrm{BH}$ & $250^{\mathrm{a}}$ & 350 & 320 & $211^{\mathrm{a}}$ & 310 & $250^{\mathrm{a}}$ & $180^{\mathrm{a}}$ & $190^{\mathrm{a}}$ & $280^{\mathrm{a}}$ \\
\hline SD & $420^{\mathrm{b}}$ & $510^{\mathrm{b}}$ & $430^{\mathrm{b}}$ & 351 & 350 & $400^{\mathrm{b}}$ & $390^{\mathrm{b}}$ & $390^{\mathrm{b}}$ & $440^{b}$ \\
\hline SW & $400^{\mathrm{a}}$ & 510 & $430^{\mathrm{a}}$ & 450 & 440 & 510 & $410^{\mathrm{a}}$ & $410^{\mathrm{a}}$ & $411^{\mathrm{a}}$ \\
\hline BW & 400 & 510 & 400 & 431 & 430 & 430 & 410 & 410 & 410 \\
\hline TW & & $390^{\mathrm{a}}$ & & $250^{\mathrm{a}}$ & $300^{\mathrm{a}}$ & & $300^{\mathrm{a}}$ & $300^{\mathrm{a}}$ & $300^{\mathrm{a}}$ \\
\hline
\end{tabular}

Note: Non-superscripted values denote the design parameters that match ideal measures, a represents low mismatch and $\mathrm{b}$ refers to high mismatch. Cells in blank represents the absence of the parameter in the furniture.

Table 4: Sample size

\begin{tabular}{|c|c|c|c|}
\hline University & Furniture & Sample & Total \\
\hline A & M1 & 137 & 137 \\
\hline \multirow{2}{*}{ B } & M2 & 89 & \multirow{2}{*}{120} \\
\cline { 2 - 3 } & M3 & 31 & \\
\hline \multirow{2}{*}{ C } & M4 & 37 & \multirow{2}{*}{105} \\
\cline { 2 - 3 } & M5 & 68 & 105 \\
\hline \multirow{2}{*}{ D } & M6 & 105 & \multirow{2}{*}{161} \\
\hline \multirow{2}{*}{ E } & M7 & 64 & \multirow{2}{*}{} \\
\cline { 2 - 3 } & M8 & 43 & \multicolumn{2}{|c}{} \\
\cline { 2 - 3 } & M9 & 54 & \\
\hline
\end{tabular}

Table 5: Estimation of annual MDS prevalence and proportion of students unable to perform regular activities as a consequence of this prevalence

\begin{tabular}{|c|c|c|}
\hline $\begin{array}{c}\text { Anatomical } \\
\text { classification of } \\
\text { MDS }\end{array}$ & $\begin{array}{c}\text { MDS prevalence } \\
\text { over the last year }\end{array}$ & $\begin{array}{c}\text { Impediment to carry } \\
\text { out daily activities } \\
\text { over the last year }\end{array}$ \\
\hline Neck & $0.636 \pm 0.038$ & $0.291 \pm 0.036$ \\
\hline Shoulders & $0.466 \pm 0.039$ & $0.199 \pm 0.031$ \\
\hline Elbows & $0.218 \pm 0.032$ & $0.120 \pm 0.026$ \\
\hline Wrists/Hands & $0.324 \pm 0.037$ & $0.246 \pm 0.034$ \\
\hline High back & $0.573 \pm 0.039$ & $0.344 \pm 0.037$ \\
\hline Low back & $0.546 \pm 0.039$ & $0.376 \pm 0.038$ \\
\hline Hips/Thighs & $0.432 \pm 0.039$ & $0.302 \pm 0.036$ \\
\hline Knees & $0.275 \pm 0.035$ & $0.183 \pm 0.030$ \\
\hline Ankles/Feet & $0.268 \pm 0.035$ & $0.151 \pm 0.028$ \\
\hline
\end{tabular}

Note: $95 \%$ confidence intervals estimation prevented from carrying out their usual activities during the same period given the presence of neck-related MDS in the last year. Students who used furniture five also showed a high prevalence of MDS associated with the shoulders $(63.24 \%)$, wrists and hands (75\%), lower back (63.24\%) and hips/thighs (64.71\%).In addition, students exposed to furniture number eight also showed high MDS prevalence in the upper back $(65.12 \%)$, lower back (67.44\%), hips/thighs (66.32\%) and ankles/feet (65.12\%). A similar analysis can be done for each group of students according to the model of furniture used in their academic activities.

Table 7 shows the OR values and their respective 95\% confidence intervals for those categories of selected variables that could be associated with MDS prevalence. When the OR value is greater than one and its confidence interval does not include the unit, then the association under study is considered statistically significant [43]. In other words, it is ruled out that the association between the analyzed variable categories and the presence of MDS in any part of the body is given by chance.

\section{Discussion}

In this study, 10 classroom furniture design parameters for university students were determined based on secondary anthropometric information corresponding to the mestizo adult population of Ecuador. Such ideal dimensions, expressed in compatibility ranges, could assure comfort to $95 \%$ of the university student population self-identified as mestizo since this ethnic group represents the majority of the population according to the last two population and housing censuses as shown in Figure 1.

These results are particularly relevant in the context of the few academic or scientific studies on school furniture design for Ecuadorian university students according to anthropometric principles. Actually, to the author's knowledge, there is only one study related to this subject [44]. However, in that work, the use of anthropometric measures included in DIN 33402 standards [45] 
P. Pérez-Gosende. / Advances in Science, Technology and Engineering Systems Journal Vol. 4, No. 6, 163-172 (2019)

Table 6: Annual MDS prevalence and annual MDS prevalence differences among students according to furniture models

\begin{tabular}{|c|c|c|c|c|c|c|c|c|c|c|}
\hline & Model & Neck & Shoulders & Elbows & $\begin{array}{l}\text { Wrists/ } \\
\text { Hands }\end{array}$ & $\begin{array}{l}\text { High } \\
\text { back }\end{array}$ & $\begin{array}{l}\text { Low } \\
\text { back }\end{array}$ & $\begin{array}{l}\text { Hips/ } \\
\text { Thighs }\end{array}$ & Knees & $\begin{array}{c}\text { Ankles/ } \\
\text { Feet }\end{array}$ \\
\hline \multirow{12}{*}{$\begin{array}{l}\text { MDS prevalence } \\
\text { over the last year }\end{array}$} & M1 & 56.20 & 42.34 & 16.79 & 29.20 & 58.39 & 62.77 & 37.96 & 25.55 & 18.25 \\
\hline & M2 & 55.06 & 38.20 & 29.21 & 33.71 & 62.92 & 38.20 & 22.47 & 24.72 & 23.60 \\
\hline & M3 & 69.23 & 46.15 & 11.54 & 23.08 & 57.69 & 38.46 & 50.00 & 30.77 & 30.77 \\
\hline & M4 & 78.38 & 56.76 & 35.14 & 45.95 & 64.86 & 62.16 & 48.65 & 27.03 & 18.92 \\
\hline & M5 & 88.24 & 63.24 & 38.24 & 75.00 & 38.24 & 63.24 & 64.71 & 50.00 & 51.47 \\
\hline & M6 & 56.19 & 44.76 & 7.62 & 22.86 & 55.24 & 60.00 & 37.14 & 22.86 & 17.14 \\
\hline & M7 & 67.19 & 59.38 & 26.56 & 15.63 & 78.13 & 62.50 & 53.13 & 7.81 & 23.44 \\
\hline & M8 & 100.00 & 48.84 & 32.56 & 32.56 & 65.12 & 67.44 & 66.32 & 48.84 & 65.12 \\
\hline & M9 & 33.33 & 29.63 & 11.11 & 18.52 & 37.04 & 22.22 & 37.04 & 22.22 & 18.52 \\
\hline & Total & 63.56 & 46.55 & 21.83 & 32.42 & 57.30 & 54.57 & 43.18 & 27.45 & 26.81 \\
\hline & & $\chi^{2}=76.51$ & $\chi^{2}=23.30$ & $\chi^{2}=40.86$ & $\chi^{2}=78.50$ & $\chi^{2}=33.85$ & $\chi^{2}=47.52$ & $\chi^{2}=46.15$ & $\chi^{2}=42.22$ & $\chi^{2}=67.47$ \\
\hline & & $\mathrm{p}=0.000^{*}$ & $\mathrm{p}=0.003^{*}$ & $\mathrm{p}=0.000^{*}$ & $\mathrm{p}=0.000 *$ & $\mathrm{p}=0.000^{*}$ & $\mathrm{p}=0.000^{*}$ & $\mathrm{p}=0.000^{*}$ & $\mathrm{p}=0.000^{*}$ & $\mathrm{p}=0.000^{*}$ \\
\hline \multirow{12}{*}{$\begin{array}{l}\text { Impediment to } \\
\text { carry out daily } \\
\text { activities over the } \\
\text { last year }\end{array}$} & M1 & 24.09 & 16.79 & 5.84 & 12.41 & 31.39 & 36.50 & 21.17 & 11.68 & 10.95 \\
\hline & M2 & 24.72 & 15.73 & 15.73 & 33.71 & 19.10 & 24.72 & 33.71 & 15.73 & 8.99 \\
\hline & M3 & 26.92 & 19.23 & 0.00 & 15.38 & 19.23 & 15.38 & 19.23 & 11.54 & 11.54 \\
\hline & M4 & 37.84 & 21.62 & 10.81 & 27.03 & 40.54 & 37.84 & 21.62 & 10.81 & 16.22 \\
\hline & M5 & 48.53 & 11.76 & 36.76 & 63.24 & 50.00 & 63.24 & 50.00 & 63.24 & 25.00 \\
\hline & M6 & 19.05 & 12.38 & 0.00 & 17.14 & 30.48 & 26.67 & 16.19 & 13.33 & 7.62 \\
\hline & M7 & 31.25 & 25.00 & 25.00 & 25.00 & 51.56 & 43.75 & 40.63 & 10.94 & 7.81 \\
\hline & M8 & 32.56 & 48.84 & 0.00 & 16.28 & 48.84 & 65.24 & 64.15 & 16.28 & 65.12 \\
\hline & M9 & 33.33 & 29.63 & 14.81 & 14.81 & 25.93 & 29.63 & 18.52 & 11.11 & 7.41 \\
\hline & Total & 29.05 & 19.90 & 12.04 & 24.56 & 34.35 & 37.56 & 30.18 & 18.30 & 15.09 \\
\hline & & $\chi^{2}=22.39$ & $\chi^{2}=35.26$ & $\chi^{2}=79.79$ & $\chi^{2}=78.62$ & $\chi^{2}=35.17$ & $\chi^{2}=55.07$ & $\chi^{2}=66.14$ & $\chi^{2}=104.47$ & $\chi^{2}=103.6$ \\
\hline & & $\mathrm{p}=0.004^{*}$ & $\mathrm{p}=0.000^{*}$ & $\mathrm{p}=0.000^{*}$ & $\mathrm{p}=0.000^{*}$ & $\mathrm{p}=0.000^{*}$ & $\mathrm{p}=0.000^{*}$ & $\mathrm{p}=0.000^{*}$ & $\mathrm{p}=0.000^{*}$ & $\mathrm{p}=0.000^{*}$ \\
\hline
\end{tabular}

Note: Prevalence is represented in percentages. The asterisk represents significant differences at a $95 \%$ confidence level between the MDS prevalence for each furniture model.

diminishes their furniture design proposal validity, given the outstanding anthropometric differences between the German and the Ecuadorian population.

The Ecuadorian technical standard NTE INEN 2583: 2011 [46] establishes the requirements for tables and chairs for students between the second year of primary education until the third year of upper secondary school, as well as the quality tests to which they must fulfill so as to prove their suitability for use. These standard does not include specific measures for the furniture of Higher Education students. In this context, the dimensions of the design parameters for tables, chairs and side-mounted desktop chairs proposed in this study, could be the starting point for the creation of a specific standard that regulates the design of school furniture for university students.

In general, every analyzed study station composed of tables and chairs in the 5 examined universities presented high discrepancy in seat height and seat depth, and also in desk height and underdesk height. Likewise, all of them presented a low mismatch in the table width and the table depth. On the other hand, every chair with side-mounted desktop analyzed showed a high mismatch in the inner and upper tablet height, as well as in seat height. The length and width of the tablet also presented a low mismatch.

This study also demonstrated a dependence between the presence of MDS in university students and the type of school furniture used during the last twelve months. Although the nine analyzed models have at least five mismatches in their design parameters, there is insufficient evidence to affirm that these incompatibilities are the only cause of MDS. Therefore, providing students with furniture that is fully compatible with their anthropometric characteristics will not necessarily guarantee the total absence of MDS.

It is recommended that future researches deepen the identification of such causes, as the prevalence levels identified in this research are quite high considering that $88.76 \%$ of the students felt MDS in at least one part of their body during the last year (95\% CI: $0.863-0.912)$. It is also important to note that among the latter, $62.92 \%$ (95\% CI: 0.591-0.667) reported having been prevented from performing other usual daily activities.

The results show that women who use the furniture models assessed are more likely than men to feel MDS associated with neck, shoulders, upper back, lower back and hips/thighs. Individuals with a BMI greater than $25 \mathrm{~kg} / \mathrm{m} 2$ (considered by the World Health Organization as being overweight/obese [47]) are at increased risk of having MDS along the entire spine and hips/thighs. Sitting longer than 20 hours a week poses a risk for the presence of MDS in the neck, lower back, and knees.

Upper-level students (third, fourth, and fifth year of study) are at increased risk of having MDS in the neck, lower back and hips/thighs. Students who use a side-mounted desktop chair on a day-to-day basis may be more likely to develop MDS in the neck, wrists/hands, and ankles/feet than students using a table and chair. The latter, are more likely to have problems in the lower back. The results also demonstrate that being left-handed and over 25 years of age are not risk factors for the presence of MDS in 
P. Pérez-Gosende. / Advances in Science, Technology and Engineering Systems Journal Vol. 4, No. 6, 163-172 (2019)

Table 7: Risk factors related to annual MDS prevalence in university students

\begin{tabular}{|c|c|c|c|c|c|c|c|c|}
\hline Caracteristics & Neck & Shoulders & $\begin{array}{l}\text { Wrists/ } \\
\text { Hands }\end{array}$ & High back & Low back & $\begin{array}{l}\text { Hips/ } \\
\text { Thighs }\end{array}$ & Knees & $\begin{array}{c}\text { Ankles/ } \\
\text { Feet }\end{array}$ \\
\hline Female gender & $\begin{array}{c}2.431^{\mathrm{a}} \\
(1.73-3.42) \\
\end{array}$ & $\begin{array}{c}2.837^{\mathrm{a}} \\
(2.05-3.93) \\
\end{array}$ & $\begin{array}{c}1.214 \\
(0.86-1.69) \\
\end{array}$ & $\begin{array}{c}1.737^{\mathrm{a}} \\
(1.25-2.40)\end{array}$ & $\begin{array}{c}1.759^{\mathrm{a}} \\
(1.27-2.42)\end{array}$ & $\begin{array}{c}1.649^{\mathrm{a}} \\
(1.19-2.27)\end{array}$ & $\begin{array}{c}0.816 \\
(0.57-1.16) \\
\end{array}$ & $\begin{array}{c}1.283 \\
(0.90-1.83) \\
\end{array}$ \\
\hline Left-handed & $\begin{array}{c}0.516 \\
(0.30-0.85)\end{array}$ & $\begin{array}{c}0.450 \\
(0.26-0.78)\end{array}$ & $\begin{array}{c}0.291 \\
(0.14-0.60) \\
\end{array}$ & $\begin{array}{c}0.216 \\
(0.12-0.38)\end{array}$ & $\begin{array}{c}0.524 \\
(0.31-0.87) \\
\end{array}$ & $\begin{array}{c}0.375 \\
(0.20-0.67) \\
\end{array}$ & $\begin{array}{c}0.326 \\
(0.15-0.69) \\
\end{array}$ & $\begin{array}{c}0.628 \\
(0.33-1.18)\end{array}$ \\
\hline Over 25 years old & $\begin{array}{c}1.062 \\
(0.52-2.12)\end{array}$ & $\begin{array}{c}0.974 \\
(0.50-1.89) \\
\end{array}$ & $\begin{array}{c}0.557 \\
(0.25-1.24) \\
\end{array}$ & $\begin{array}{c}1.239 \\
(0.62-2.45)\end{array}$ & $\begin{array}{c}0.692 \\
(0.35-1.34) \\
\end{array}$ & $\begin{array}{c}0.891 \\
(0.45-1.75) \\
\end{array}$ & $\begin{array}{c}0.977 \\
(0.46-2.06) \\
\end{array}$ & $\begin{array}{c}1.166 \\
(0.56-2.41) \\
\end{array}$ \\
\hline $\begin{array}{l}\text { BMI higher than } \\
25 \mathrm{Kg} / \mathrm{m}^{2}\end{array}$ & $\begin{array}{c}0.694 \\
(0.49-0.98)\end{array}$ & $\begin{array}{c}0.758 \\
(0.54-1.06)\end{array}$ & $\begin{array}{c}0.758 \\
(0.53-1.09)\end{array}$ & $\begin{array}{c}3.151^{\mathrm{a}} \\
(2.00-4.95)\end{array}$ & $\begin{array}{c}4.331^{\mathrm{a}} \\
(2.23-8.40)\end{array}$ & $\begin{array}{c}2.581^{\mathrm{a}} \\
(1.83-3.63)\end{array}$ & $\begin{array}{c}0.906 \\
(0.62-1.32)\end{array}$ & $\begin{array}{c}0.884 \\
(0.61-1.29)\end{array}$ \\
\hline $\begin{array}{l}\text { To be seated more } \\
\text { than } 20 \text { hours a } \\
\text { week }\end{array}$ & $\begin{array}{c}1.968^{\mathrm{a}} \\
(1.17-3.29)\end{array}$ & $\begin{array}{c}0.721 \\
(0.52-0.98)\end{array}$ & $\begin{array}{c}1.064 \\
(0.76-1.48)\end{array}$ & $\begin{array}{c}0.575 \\
(0.41-0.79)\end{array}$ & $\begin{array}{c}2.387^{\mathrm{a}} \\
(1.60-3.55)\end{array}$ & $\begin{array}{c}0.839 \\
(0.61-1.15)\end{array}$ & $\begin{array}{c}1.590^{\mathrm{a}} \\
(1.11-2.27)\end{array}$ & $\begin{array}{c}0.843 \\
(0.59-1.20)\end{array}$ \\
\hline $\begin{array}{l}\text { More than } 2 \text { years } \\
\text { studying }\end{array}$ & $\begin{array}{c}1.766^{\mathrm{a}} \\
(1.02-3.03)\end{array}$ & $\begin{array}{c}0.949 \\
(0.67-1.34)\end{array}$ & $\begin{array}{c}1.449 \\
(0.99-2.13)\end{array}$ & $\begin{array}{c}1.195 \\
(0.84-1.69)\end{array}$ & $\begin{array}{c}1.492^{\mathrm{a}} \\
(1.05-2.11)\end{array}$ & $\begin{array}{c}1.648^{\mathrm{a}} \\
(1.15-2.36)\end{array}$ & $\begin{array}{c}2.850 \\
(1.80-4.52)\end{array}$ & $\begin{array}{c}1.278 \\
(0.85-1.91)\end{array}$ \\
\hline $\begin{array}{l}\text { Use of side- } \\
\text { mounted desktop } \\
\text { chair }\end{array}$ & $\begin{array}{c}1.585^{\mathrm{a}} \\
(1.14-2.20)\end{array}$ & $\begin{array}{c}1.227 \\
(0.89-1.69)\end{array}$ & $\begin{array}{c}1.674^{\mathrm{a}} \\
(1.18-2.37)\end{array}$ & $\begin{array}{c}1.015 \\
(0.74-1.40)\end{array}$ & $\begin{array}{c}0.713 \\
(0.52-0.98)\end{array}$ & $\begin{array}{c}1.369 \\
(0.99-1.89)\end{array}$ & $\begin{array}{c}1.243 \\
(0.87-1.78)\end{array}$ & $\begin{array}{c}2.065^{\mathrm{a}} \\
(1.42-3.01)\end{array}$ \\
\hline Use of table/chair & $\begin{array}{c}0.631 \\
(0.45-0.88) \\
\end{array}$ & $\begin{array}{c}0.815 \\
(0.59-1.12) \\
\end{array}$ & $\begin{array}{c}0.597 \\
(0.42-0.85 \\
\end{array}$ & $\begin{array}{c}0.985 \\
(0.72-1.36) \\
\end{array}$ & $\begin{array}{c}1.402^{\mathrm{a}} \\
(1.02-1.93) \\
\end{array}$ & $\begin{array}{c}0.730 \\
(0.53-1.01) \\
\end{array}$ & $\begin{array}{c}0.804 \\
(0.56-1.15) \\
\end{array}$ & $\begin{array}{c}0.484 \\
(0.33-0.71) \\
\end{array}$ \\
\hline
\end{tabular}

Note: Values correspond to OR. Ranges in parentheses stand for $95 \%$ OR confidence intervals. Superscript represents the OR is significant at a $95 \%$ confidence level.

university students.

In considering the presence of MDS in the nine parts of the body as nominal variables, the statistical techniques that could be applied were limited. In this regard, in addition to the presence of MDS it is recommended to study the intensity of pain perceived by students, this would increase the spectrum of statistical tools that could be used to delve into the problem.

The imminent solution to avoid the high prevalence of MDS in the students of the analyzed universities would be to change all school furniture in the short term, however, such corrective measure is impractical due to the high amount of the initial investment. A more economical alternative would be to adopt the policy of taking five minutes of active pauses between each hour of work in the classroom so that students can stretch their limbs and reduce exposure to bad postures that can produce pain, swelling, paresthesia, or any other musculoskeletal disorder symptom.

The human body is not designed to remain seated for long periods of time. Intervertebral discs do not have an independent blood supply and depend on the pressure changes that result from the body movement to receive nutrients and to discard their metabolic wastes [41]. The rigidity of the posture also reduces blood flow to the muscles and induces muscle fatigue and cramps [41].

In the same way, it would be advisable for higher education institutions to carry out campaigns to promote awareness in students about the importance to adopt the right postures when performing academic activities in a seated position.

\section{Conclusions}

This research determined ten design parameters for classroom furniture design for Ecuadorian university students based on relevant anthropometric information. Classroom furniture here examined were composed of tables with its correspondent chairs, and also side-mounted desktop chairs. These results are particularly relevant as they could stand as a starting point to the creation of a specific Ecuadorian standard to regulate classroom furniture design for university students. That would ensure domestic and foreign manufacturers could offer furniture more secure and adequate to the anthropometric characteristics of the university population of Ecuador.

Taking the above-mentioned measures as a reference, a sample of 9 school furniture models that were used in 5 universities of the city of Guayaquil was evaluated based on the computed match intervals and it was found that $100 \%$ does not fit, in at least five design parameters, to the anthropometric characteristics of its target population. Only the width of the chair backrest was within the matching range.

A high prevalence of musculoskeletal disorders symptoms (MDS) was found in students over the last year, mainly in the neck, along the whole spine and in the hips or thighs. Also, the percentage of students who reported having perceived these symptoms and thereby prevented other usual non-academic activities were significantly different for each model of furniture. This demonstrated that there is a relationship of dependence between the type of furniture and the presence of MDS in some parts of the body.

This study also showed evidence that female students who 
spend more than 20 hours per week sitting at a side-mounted desktop chair are at greater risk of having MDS in the neck than men. Also, women who are overweight or obese (BMI over 25 $\mathrm{kg} / \mathrm{m}^{2}$ ) are at higher risk of having MDS in the upper back and hips or thighs, and those that have studied more than two years in higher education institutions and spend more than 20 weekly hours using desk and chair study stations have a greater risk of having MDS in the lower back.

All of the above-mentioned findings support the need to extend the research immediately to a national level to identify the real prevalence of MDS in the Ecuadorian university students, provide the required medical rehabilitation if necessary, and establish a strategy that allows the gradual acquisition of safer and appropriate classroom furniture that matches students' anthropometric characteristics.

\section{Conflict of Interest}

The author declares no conflict of interest with any individual or organization.

\section{Acknowledgment}

The author would like to thank Universidad Politécnica Salesiana for funding this research. Also, a special acknowledge is dedicated to all the industrial engineering students who helped to collect relevant data.

\section{References}

[1] Centers for Disease Control and Prevention, "National health and nutrition examination survey (NHANES) anthropometry procedures manual," USA, 2016.

[2] I. Dianat, M. Kord, P. Yahyazade, M. A. Karimi, A. W. Stedmon, "Association of individual and work-related risk factors with musculoskeletal symptoms among Iranian sewing machine operators," Appl. Ergon.,51, 2015, https://doi.org/10.1016/j.apergo.2015.04.017.

[3] M. M. Robertson, Y. H. Huang, J. Lee, "Improvements in musculoskeletal health and computing behaviors: Effects of a macroergonomics office workplace and training intervention,” Appl. Ergon., 62, 182-196, 2017, https://doi.org/10.1016/j.apergo.2017.02.017.

[4] M. K. Gouvali and K. Boudolos, "Match between school furniture dimensions and children's anthropometry," Appl. Ergon.,37, no. 6, 2006, https://doi.org/10.1016/j.apergo.2017.02.017.

[5] Z. Z. Afzan, S. A. Hadi, B. T. Shamsul, H. Zailina, I. Nada, A. R. S. Rahmah, "Mismatch between school furniture and anthropometric measures among primary school children in Mersing, Johor, Malaysia," in 2012 Southeast Asian Network of Ergonomics Societies Conference: Ergonomics Innovations Leveraging User Experience and Sustainability (SEANES), Langkawi, Malaysia, 2012.

[6] G. Adu, S. Adu, B. Effah, K. Frimpong-Mensah, N. A. Darkwa, "Office Furniture Design-Correlation of Worker and Chair Dimensions," Int. J. Sci. Res., 3, no. 3, 709-715, 2014.

[7] I. T. G. Souza, C. R. B. Buski, E. C. Batiz, A. L. B. Hurtado, "Ergonomic Analysis of a Clothing Design Station," Procedia Manuf., 3, 4362-4369, 2015, https://doi.org/10.1016/j.promfg.2015.07.432.

[8] M. Azuan, H. Zailina, B. M. T. Shamsul, N. Asyiqin, M. N. Azhar, I. S. Aizat, "Neck, upper back and lower back pain and associated risk factors among primary school children,” J. Appl. Sci., 10(5), 431-435, 2010, https://doi.org/10.3923/jas.2010.431.435.

[9] G. A. Mirka, C. Shivers, C. Smith, J. Taylor, "Ergonomic interventions for the furniture manufacturing industry. Part II-Handtools, " Int. J. Ind. Ergon., 29(5), 275-287, 2002, https://doi.org/10.1016/S0169-8141(01)00068-3.

[10] Y. Zakeri, M. Gheibizadeh, S. Baraz, D. B. Nejad, S. M. Latifi, "The relationship between features of desks and chairs and prevalence of skeletal disorders in primary school students in Abadan, South West of Iran,” Int. J. Pediatr., 4 (11), 3949-3956, 2016, https://doi.org/10.22038/ijp.2016.7656.

[11] S. R. Agha, "School furniture match to students' anthropometry in the Gaza Strip," Ergonomics, 53(3), 344-354, 2010, https://doi.org/10.1080/00140130903398366.

[12] M. Mokdad and M. Al-Ansari, "Anthropometrics for the design of Bahraini school furniture," Int. J. Ind. Ergon., 39(5), 728-735, 2009, https://doi.org/10.1016/j.ergon.2009.02.006.

[13] A. I. Musa, "Anthropometric evaluations and assessment of school furniture design in Nigeria: A case study of secondary schools in rural area of Odeda, Nigeria," Int. J. Ind. Eng. Comput., 2(3), 499-508, 2011, https://doi.org/10.5267/j.ijiec.2011.03.006.

[14] I. W. Taifa and D. A. Desai, "Anthropometric measurements for ergonomic design of students' furniture in India," Eng. Sci. Technol. an Int. J., 1-8, 2016, https://doi.org/10.1016/j.jestch.2016.08.004.

[15] B. W. Niebel and A. Freivalds, Ingeniería industrial: métodos, estándares y diseño del trabajo, $13^{\text {th }}$ ed. Ciudad de México, México: McGraw-Hill, 2014.

[16] M. G. Mohamed Thariq, H. P. Munasinghe, J. D. Abeysekara, "Designing chairs with mounted desktop for university students: Ergonomics and comfort," Int. J. Ind. Ergon., 40(1), 8-18, 2010, https://doi.org/10.1016/j.ergon.2009.10.003.

[17] H. I. Castellucci, P. M. Arezes, J. F. M. Molenbroek, "Equations for defining the mismatch between students and school furniture: A systematic review," Int. J. Ind. Ergon., 48, 117-126, 2015, https://doi.org/10.1016/j.ergon.2015.05.002.

[18] I. W. Taifa and D. A. Desai, "Anthropometric measurements for ergonomic design of students' furniture in India,” Eng. Sci. Technol. an Int. J., 20(1), 232-239, 2017, https://doi.org/ 10.1016/j.jestch.2016.08.004.

[19] H. I. Castellucci, P. M. Arezes, J. F. M. Molenbroek, “Applying different equations to evaluate the level of mismatch between students and school furniture," Appl. Ergon., 45(4), 1123-1132, 2014, https://doi.org/10.1016/j.apergo.2014.01.012.

[20] H. I. Castellucci, P. M. Arezes, J. F. M. Molenbroek, “Analysis of the most relevant anthropometric dimensions for school furniture selection based on a study with students from one Chilean region," Appl. Ergon., 46, 201-211, 2015, https://doi.org/10.1016/j.apergo.2014.08.005.

[21] A. Altaboli, M. Belkhear, A. Bosenina, N. Elfsei, "Anthropometric Evaluation of the Design of the Classroom Desk for the Fourth and Fifth Grades of Benghazi Primary Schools," Procedia Manuf., 3, 5655-5662, 2015, https://doi.org/10.1016/j.promfg.2015.07.778.

[22] I. Dianat, M. A. Karimi, A. Asl Hashemi, S. Bahrampour, "Classroom furniture and anthropometric characteristics of Iranian high school students: Proposed dimensions based on anthropometric data," Appl. Ergon., 44(1), 101-108, 2013, https://doi.org/10.1016/j.apergo.2012.05.004.

[23] H. I. Castellucci, M. Catalán, P. M. Arezes, J. F. M. Molenbroek, "Evidence for the need to update the Chilean standard for school furniture dimension specifications," Int. J. Ind. Ergon., 56, 181-188, 2016, https://doi.org/10.1016/j.ergon.2015.09.019.

[24] J. M. Mahoney, N. A. Kurczewski, E. W. Froede, "Design method for multiuser workstations utilizing anthropometry and preference data," Appl. Ergon., 46, 60-66, 2015, https://doi.org/10.1016/j.apergo.2014.07.003.

[25] F. W. Cayo-Chiluisa, "El diseño de estaciones de trabajo escolar y su incidencia en el proceso de enseñanza aprendizaje en niños y niñas de 3 a 5 años del Centro de desarrollo infantil y estimulación temprana pequeños traviesos de la Ciudad de Latacunga," Universidad Técnica de Ambato, 2014.

[26] A. C. Viera-Meléndez, "Análisis ergonómico del mobiliario escolar en relación a las medidas antropométricas y evaluación postural de los niños del 6to año de educación básica de la escuela 'Quintiliano Sánchez'," Quito, Pontificia Universidad Católica del Ecuador, 2012.

[27] M. del R. Pomboza-Fioril and V. A. Cloquell-Ballester, "Determinación antropométrica para mobiliario escolar destinado a niños con discapacidad motriz en Ecuador," Cienc. Trab., 17(53), 154-158, 2015.

[28] J. L. Alarcón-Escobar, "Diseño de mobiliario escolar para niños y niñas con paraparesia espástica del instituto fiscal de discapacidad motriz," Pontificia Universidad Católica del Ecuador, 2016.

[29] P. Romo-Cardoso and T. del Campo-Balsa, "Trastornos musculoesqueléticos en trabajadores sanitarios y su valoración mediante cuestionarios de discapacidad y dolor," Med. del Trab., 20(1), 27-33, 2011.

[30] A. Genç, T. Kahraman, E. Göz, "The prevalence differences of 
musculoskeletal problems and related physical workload among hospital staff," J. Back Musculoskelet. Rehabil., 29(3), 541-547, 2016, https://doi.org/10.3233/BMR-160655.

[31] M. Mendinueta-Martínez and Y. H. Herazo-Beltrán, "Perception musculoskeletal discomfort and postural risk among employees of a higher education institution," Salud Uninorte, 30(2), 170-179, 2014.

[32] R. M. Rosario Amézquita and T. I. Amézquita Rosario, "Prevalencia de trastornos músculo-esqueléticos en el personal de esterilización en tres hospitales públicos,” Med. Segur. Trab., 60(234), 24-43, 2014, https://doi.org/10.4321/S0465-546X2014000100004.

[33] I. Kuorinka, B. Jonsson, A. Kilbom, H. Vinterberg, F. Biering-Sørensen, G. Andersson, K. Jørgensen, "Standardised Nordic questionnaires for the analysis of musculoskeletal symptoms," Appl. Ergon., 18(3), 233-237, 1987.

[34] A. Tezel, "Musculoskeletal complaints among a group of Turkish nurses," Int. J. Neurosci., 115(6), 871-880, 2005, https://doi.org/10.1080/00207450590897941.

[35] M. Mendinueta, Y. Herazo, Y. Pinillos, "Factores asociados a la percepción de dolor lumbar en trabajadores de una empresa de transporte terrestre.," Salud Uninorte, 30(2), 192-199, 2014.

[36] T. Kahraman, A. Genç, E. Göz, "The Nordic Musculoskeletal Questionnaire: cross-cultural adaptation into Turkish assessing its psychometric properties," Disabil. Rehabil., 38(21), 2153-2160, 2016, https://doi.org/10.3109/09638288.2015.1114034.

[37] D. V. Lema-Barrera, "Comparación estadística de medidas antropométricas entre mestizos, indígenas y afro ecuatorianos de la Región Sierra del Ecuador," MSc Thesis, Universidad San Francisco de Quito, 2013.

[38] Instituto Nacional de Estadística y Censos (INEC), Base de datos Censo de población y viviendas 2001, 2001. Available: http://www.ecuadorencifras.gob.ec/base-de-datos-censo-de-poblacion-yvivienda-2001.

[39] Instituto Nacional de Estadística y Censos (INEC), Base de datos Censo de población y viviendas 2010, 2010. Available: $\mathrm{http}: / / w w w . e c u a d o r e n c i f r a s . g o b . e c / b a s e-d e-d a t o s-c e n s o-d e-p o b l a c i o n-y-$ vivienda-2010.

[40] ISO, Basic human body measurements for technological design-Part 1: Body measurement definitions and landmarks (ISO 7250-1:2008), 2008.

[41] C. Parcells, M. Stommel, R. P. Hubbard, "Mismatch of classroom furniture and student body dimensions," J. Adolesc. Heal., 24(4), 265-273, 1999, https://doi.org/10.1016/S1054-139X(98)00113-X.

[42] ISO, "Ergonomic requirements for office work with visual display terminals (VDTs). Part 5: Workstation layout and postural requirements (ISO 92415:1998), 1998.

[43] J. Cerda, C. Vera, G. Rada, "Odds ratio: aspectos teóricos y prácticos," Rev. Med. Chil., 141(10), 1329-1335, 2013, https://doi.org/10.4067/S003498872013001000014.

[44] P. S. Espinosa-Tabango, "Diseño de una estación de trabajo para los estudiantes de la Universidad Central del Ecuador," Eng Thesis, Universidad Central del Ecuador, 2013.

[45] Deutsches Institut für Normung. DIN 33402-2 Ergonomie - Körpermaße des Menschen - Tail 2, Berlín, 1981.

[46] Instituto ecuatoriano de normalización (INEN), NTE INEN 2583: 2011 Muebles escolares. Pupitre con silla para alumnos. Requisitos e inspección. Quito, Ecuador, 2011.

[47] OMS, "Obesity: preventing and managing the global epidemic," Geneva, Switzerland, 2000. 